\title{
Partial Replacement of Fish Oil in Tra Catfish (Pangasianodon hypophthalmus) Diet with Different Levels of LYSOFORTE ${ }^{\mathrm{TM}}$ Dry
}

\author{
L.V. Bindhu, C. Sugumar, and Maria Glenda D. Esperida \\ Kemin Industries (Asia) Pte Ltd, 12 Senoko Drive, Singapore \\ Email: bindhulv@kemin.com
}

\begin{abstract}
L.V. Bindhu., C. Sugumar, and Maria Glenda D. Esperida. 2016. Partial Replacement of Fish Oil in Tra Catfish (Pangasianodon hypophthalmus) Diet with Different Levels of LYSOFORTETM Dry. Aquacultura Indonesiana. 17 (1): 12-19. Phospholipids are known to play a significant role in lipid transport in crustaceans. LYSOFORTETM is a bio-emulsifier enriched with lysophospholipids used in animal feeds to improve the digestion and absorption of fat. Objective of the current study was to evaluate the growth promoting effect and fish oil sparing effect of LYSOFORTETM Dry in Tra Catfish (Pangasianodon hypophthalmus) diets. This study comprised four treatment groups: positive control diet (T1) with $1 \%$ fish oil, negative control diet (with 1\% less fish oil) (T2), negative control diet + LYSOFORTE ${ }^{\mathrm{TM}}$ Dry $(0.05 \%)$ (T3) and negative control diet + LYSOFORTE ${ }^{\mathrm{TM}}$ Dry $(0.10 \%)(\mathrm{T} 4)$. Each treatment group comprised 3 replicates with 50 juveniles (mean body weight, $20 \mathrm{~g} \pm 0.1$ ) /replicate. Negative control treatments with LYSOFORTE at $0.05 \%$ and $0.10 \%$ improved the average body weight gain by $16.08 \mathrm{~g}$ and $25.74 \mathrm{~g}(P>0.05)$ with a corresponding FCR improvement of 1 point and 11 points respectively. Specific growth rate improved by $0.18 \% /$ day $(0.05 \%$ LYSOFORTETM Dry) and $0.28 \%$ /day (0.1\% LYSOFORTETM Dry). Survival percentage also improved in the negative control diets supplemented with LYSOFORTETM Dry by $6.67 \%$. Protein efficiency ratio increased by 0.22 (T3) and 0.11 (T4) whereas protein retention improved by $4.89 \%$ (T3) and $3.63 \%$ (T4) with respect to the negative control diet (T2). Lipid retention increased with the use of LYSOFORTETM Dry: 27\% for T3 and 37\% for T4 $(P<0.05)$. Moreover, fish fed with negative control diet with $0.10 \%$ of LYSOFORTETM Dry showed on par performance with those fed on the positive control diet. The results suggested the potential of formulating cat fish diets with less fish oil using LYSOFORTE ${ }^{\text {TM }}$ Dry
\end{abstract}

Keywords: Aquaculture; Bio-emulsifier; Fish oil; Growth rate; LYSOFORTETM Dry; Protein retention; Tra Catfish

\section{Introduction}

The striped catfish or tra cat fish (Pangasianodon hypophthalmus), farming sector has emerged as an icon of aquaculture development globally and currently accounts for the production of over one million tonnes with an export income exceeding US\$ 1 billion. Tra fish culture industry has been facing several challenges such as disease outbreaks, environmental pollution and high investment cost for farming the species. Above all, increasing cost of feed ingredients is one of the big challenges for sustainable farming. Typically, feed cost for Tra catfish farming is approximately $80 \%$ of total cost of investment. Although protein and lipid sources are the key ingredients that supply essential nutrients for Catfish, these ingredients contribute to over $60 \%$ cost of feed. Hence, reducing feed cost will definitely help to improve profitability and sustainability.

Phospholipids act as emulsifiers and facilitate the digestion and absorption of fat and other lipid-soluble nutrients. The inclusion of phospholipids in the diet can improve culture performance of many fish species (Coutteau et al., 1997). The beneficial effects of dietary phospholipids in fish include improved growth in both larvae and early juveniles, increased survival rates and decreased incidence of malformation in larvae, and perhaps increased stress resistance (Coutteau et al., 1997; Cahu et al., 2003). Dietary phospholipids play a significant role in lipid transport in crustaceans by transporting absorbed lipids from the gut epithelium into the hemolymph, and by facilitating lipid transport between tissues and organs (Coutteau et al., 1997). Although initial studies indicated that the requirement of dietary phospholipids may be restricted to early life stages of fish, limited data is available to demonstrate the effect of phospholipids in adult fish (Dapra et al., 2011; Taylor et al., 2015).

LYSOFORTE $^{\text {TM }}$ is a natural bioemulsifier enriched with lysophospholipids used widely in animal feeds to improve the digestion and absorption of fat. Earlier studies using LYSOFORTE $^{\mathrm{TM}}$ demonstrated the efficacy of the 
product in improving performance of post larvae of the pacific white shrimp, Litopaneaus Vannamei, Sea bass, juvenile carp and Penaeus monodon. This paper summarises the results of a trial which evaluated the efficacy of LYSOFORTETM for its growth promoting and fish oil sparing effect in Tra Catfish (Pangasianodon Hypophthalmus) diets.

\section{Materials and Methods}

The trial was conducted at the Laboratory of Fish Nutrition of Research Institute for Aquaculture No.2 (RIA2), Center for Fish Nutrition and Post-Harvest Technology (CEFIPOHATEC) in Vietnam

\section{Experimental Design}

Healthy and similar size Tra Catfishes originated from Mekong Delta were selected for the trial. Tra Catfish juveniles (initial mean body weight, $20 \mathrm{~g} \pm 0.1 \mathrm{~g}$ ) were stocked at the National Breeding Center for Southern Freshwater Aquaculture (An Thai Trung Commune, Cai Be District, Tien Giang Province) and then transferred to the Lab of fish nutrition, Research Institute for Aquaculture No.2 (RIA2), Center for Fish Nutrition and Post-harvest Technology (CEFIPOHATEC) in Vietnam. Tra Catfish juveniles were stocked in fiberglass tanks for acclimatization before the feeding trial. During the acclimatized period of 2.5 weeks, fish were fed commercial diet and then gradually adapted with the experimental feeds. Fish were starved for 24 hours before they were transferred into the experimental tanks. Water was stored for stabilization and sensory tested for quality before using for the experiments. Fiberglass tanks of 0.5 $\mathrm{m}^{3}$ water volume were used for the trials.

\section{Husbandry}

Fish were fed twice daily (8:00 and 16:00) to satiation for 90 days. After 30 minutes feeding, uneaten feed, leftover feed in the bottle and feed consumed were recorded daily. During the feeding trial, faeces were siphoned and water supplied from 3 to 4 times every week.

\section{Environmental parameters}

- Temperature $\left({ }^{0} \mathrm{C}\right)$ and $\mathrm{pH}$ : measured using pH meter HANA (2 times per day at 8:30 and 14:30);
- Dissolved oxygen (DO) (mg/L): measured using DO meter- HANA (once a week at 10:00 am);

- Determination of $\mathrm{NH}_{3}-\mathrm{N}(\mathrm{mg} / \mathrm{L})$ and $\mathrm{NO}_{2}-$ $\mathrm{N}$ (mg/L) concentration: using SERA test kit (once a week)

Diets used for the trial are given in Table 1. Experimental diets were manufactured at the feed mill of RIA2 using extrusion system. Composition of the diets used for the trial is given in Table 2 and the proximate composition of diets is given in Table 3 .

\section{Parameters Tested}

The following parameters were monitored.

- Growth performance and feed utilization

- Weight gain (WG): WG $(\mathrm{g})=\mathrm{Wf} / \mathrm{Nf}-$ $\mathrm{Wi} / \mathrm{Ni}$

- Specific growth rate (SGR):

- $\quad \operatorname{SGR}(\%$ per day $)=100^{*}[\mathrm{Ln}(\mathrm{Wf} / \mathrm{Nf})-$ $\mathrm{Ln}(\mathrm{Wi} / \mathrm{Ni})] / \mathrm{T}$

- Survival rate definition (SUR): SUR (\%) $=\mathrm{Nf} / \mathrm{Ni} * 100$

- Feed conversion ratio (FCR): FCR = $\mathrm{I} /(\mathrm{Wf}-\mathrm{Wi}+\mathrm{Wd})$

- Protein efficiency ratio (PER): PER = WG/MP

- Protein retention (PR): PR (\%) = $(\mathrm{Wf} * \mathrm{CPt}-\mathrm{Wi} * \mathrm{CP} 0+\mathrm{Wd} * \mathrm{CP} 0) / \mathrm{I} * \mathrm{CPf}$

- $\quad$ Lipid retention (LR): LR $(\%)=(\mathrm{Wf} * \mathrm{CLt}$ $\left.-\mathrm{Wi}^{*} \mathrm{CL} 0+\mathrm{Wd}{ }^{*} \mathrm{CL} 0\right) / \mathrm{I} * \mathrm{CLf}$

- Feed intake (FI): FI (\% per day) = $100 * \mathrm{I} /[(\mathrm{Wi}+\mathrm{Wf}) / 2 * \mathrm{~T}]$

Where,

- I (g) is total feed consumption on a dry weight basis

- Wi $(\mathrm{g})$ is total initial body weight

- Wf (g) is total final body weight

- $\mathrm{Wd}(\mathrm{g})$ is total body weight of the dead fish

- $\mathrm{Ni}$ is number of fish at the start

- $\mathrm{Nf}$ is number of fish at the end of the trial

- $\mathrm{T}$ (day) is duration of the trial

- $\mathrm{MP}(\mathrm{g} / \mathrm{kg})$ is total protein content of the test diets

- $\mathrm{CPt}(\mathrm{g} / \mathrm{kg})$ is protein content in whole fish body at the end of the trial

- $\mathrm{CP} 0(\mathrm{~g} / \mathrm{kg})$ is protein content in whole fish body at the start of the trial

- $\mathrm{CPf}(\mathrm{g} / \mathrm{kg})$ is protein content of the test diets 
- $\quad$ CLt $(\mathrm{g} / \mathrm{kg})$ is lipid content in whole fish body at the end of the trial

- CL0 $(\mathrm{g} / \mathrm{kg})$ is lipid content in whole fish body at the start of the trial

- $\operatorname{CLf}(\mathrm{g} / \mathrm{kg})$ is lipid content of the test diets
Statistics: Data was analysed using Microsoft Excel and a statistic software named SPSS 16.0.

Table 1. Treatments used for the trial

\begin{tabular}{ccc}
\hline Treatment & Group & Description \\
\hline T1 & Positive Control (PC) & Basal diet \\
T2 & Negative Control (NC) & Basal diet - Less 1\% Fish oil \\
T3 & NC + LYSOFORTETM & Negative control diet + 0.05\% LYSOFORTETM \\
T4 & NC + LYSOFORTETM & Negative control diet + 0.1\% LYSOFORTE \\
\hline
\end{tabular}

Table 2. Composition of experimental diets $(\mathrm{kg})$

\begin{tabular}{|c|c|c|c|c|}
\hline Feed ingredient & $\begin{array}{l}\text { Positive } \\
\text { control } \\
(T 1)\end{array}$ & $\begin{array}{l}\text { Negative control } \\
+ \text { LYSOFORTE }^{\mathrm{TM}} \\
(\mathrm{T} 2)\end{array}$ & $\begin{array}{l}\text { Negative control }+ \\
0.05 \% \text { LYSOFORTE } \\
(T 3)\end{array}$ & $\begin{array}{l}\text { Negativer control } \\
+0.1 \% \text { LYSOFORTE } \\
(T 4)\end{array}$ \\
\hline Cassava-Piece & 120.000 & 120.000 & 120.000 & 120.000 \\
\hline Rice bran & 359.580 & 373.590 & 372.090 & 371.590 \\
\hline Wheat bran & 100.000 & 100.000 & 100.000 & 100.000 \\
\hline SBMHipro (USA) & 249.000 & 249.000 & 249.000 & 249.000 \\
\hline Rape seed meal & 30.000 & 30.000 & 30.000 & 30.000 \\
\hline MBM 50\% & 75.000 & 71.000 & 72.000 & 72.000 \\
\hline Fish Meal 60\% & 50.000 & 50.000 & 50.000 & 50.000 \\
\hline Fish Oil & 10.000 & 0 & 0 & 0 \\
\hline Catfish Premix & 2.500 & 2.500 & 2.500 & 2.500 \\
\hline $\begin{array}{l}\text { Choline Chloride } \\
60 \%\end{array}$ & 0.500 & 0.500 & 0.500 & 0.500 \\
\hline VIT.C Coated & 0.500 & 0.500 & 0.500 & 0.500 \\
\hline Selen-glycinate & 0.020 & 0.020 & 0.020 & 0.020 \\
\hline DL-Methionine & 2.450 & 2.440 & 2.440 & 2.440 \\
\hline Alpha D3 & 0.250 & 0.250 & 0.250 & 0.250 \\
\hline LYSOFORTETM & 0 & 0 & 0.500 & 1.000 \\
\hline Endox-C & 0.200 & 0.200 & 0.200 & 0.200 \\
\hline
\end{tabular}

Table 3. Proximate composition of experimental diets

\begin{tabular}{llllll}
\hline Parameter & $\begin{array}{l}\text { Positive } \\
\text { control } \\
(T 1)\end{array}$ & $\begin{array}{l}\text { Negative control } \\
+ \text { LYSOFORTE }^{\mathrm{TM}}\end{array}$ & $\begin{array}{l}\text { Negative control } \\
\text { LYSOFORTE } \\
(\text { T3) }\end{array}$ & $+\begin{array}{l}\text { 0.05\% } \\
(\text { T3) }\end{array}$ & $\begin{array}{l}\text { Negative control }+ \\
0.1 \% \text { LYSOFORTE }^{\mathrm{TM}} \\
(\text { T4) }\end{array}$ \\
\hline Protein $(\%)$ & 26.01 & 25.99 & 26.02 & 26.01 \\
Fat $(\%)$ & 6.95 & 6.11 & 6.10 & 6.10 \\
Fiber $(\%)$ & 5.10 & 5.20 & 5.19 & 5.19 \\
Moisture $(\%)$ & 10.10 & 10.22 & 10.21 & 10.20 \\
Ash $(\%)$ & 7.56 & 7.60 & 7.61 & 7.61 \\
\hline
\end{tabular}




\section{Results}

Results

of

supplementing in Table 4 and 5 . Water quality data is given in Figures 1 to 5 .

LYSOFORTETM to Tra Catfish diets are shown

Table 4. Effect of adding LYSOFORTETM on body weight gain, growth rat and survival of Tra Cat fish

\begin{tabular}{|c|c|c|c|c|c|}
\hline Treatments & $\begin{array}{c}\text { Initial } \\
\text { Body weight (g) }\end{array}$ & $\begin{array}{l}\text { Final body } \\
\text { weight }(g)\end{array}$ & $\begin{array}{l}\text { Weight gain } \\
(\mathrm{g})\end{array}$ & $\begin{array}{l}\text { Specific growth } \\
\text { rate (\% per day) }\end{array}$ & Survival (\%) \\
\hline Positive Control (PC) & 23.50 & 112.29 & 88.79 & 1.68 & 97.33 \\
\hline Negative Control (NC) & 23.65 & 93.29 & 69.65 & 1.45 & 93.33 \\
\hline $\mathrm{NC}+$ LYSOFORTETM $0.05 \%$ & 23.71 & 109.43 & 85.73 & 1.63 & 100 \\
\hline NC + LYSOFORTETM $0.1 \%$ & 23.67 & 119.07 & 95.39 & 1.73 & 100 \\
\hline$p$-value & 0.9553 & 0.4382 & 0.4399 & 0.3988 & 0.5115 \\
\hline
\end{tabular}

Table 5. Effect of adding LYSOFORTETM on Feed intake, feed conversion ratio, protein efficiency ratio, protein and lipid retention of Tra Catfish

\begin{tabular}{|c|c|c|c|c|c|}
\hline Treatments & $\begin{array}{l}\text { Feed intake } \\
\text { (g per day) }\end{array}$ & $\begin{array}{c}\text { Feed conversion } \\
\text { ratio }\end{array}$ & $\begin{array}{c}\text { Protein } \\
\text { efficiency ratio }\end{array}$ & $\begin{array}{c}\text { Protein } \\
\text { retention (\%) }\end{array}$ & $\begin{array}{c}\text { Lipid retention } \\
(\%)\end{array}$ \\
\hline Positive Control (PC) & 1.15 & 1.20 & 2.84 & 43.76 & 156.95 \\
\hline Negative Control (NC) & 0.96 & 1.31 & 2.76 & 42.11 & 163.30 \\
\hline NC + LYSOFORTETM $0.05 \%$ & 1.18 & 1.30 & 2.98 & 47.00 & 190.56 \\
\hline NC + LYSOFORTETM $0.1 \%$ & 1.23 & 1.20 & 2.87 & 45.74 & 200.30 \\
\hline$p$-value & 0.4574 & 0.1835 & 0.3740 & 0.0702 & 0.0000 \\
\hline
\end{tabular}

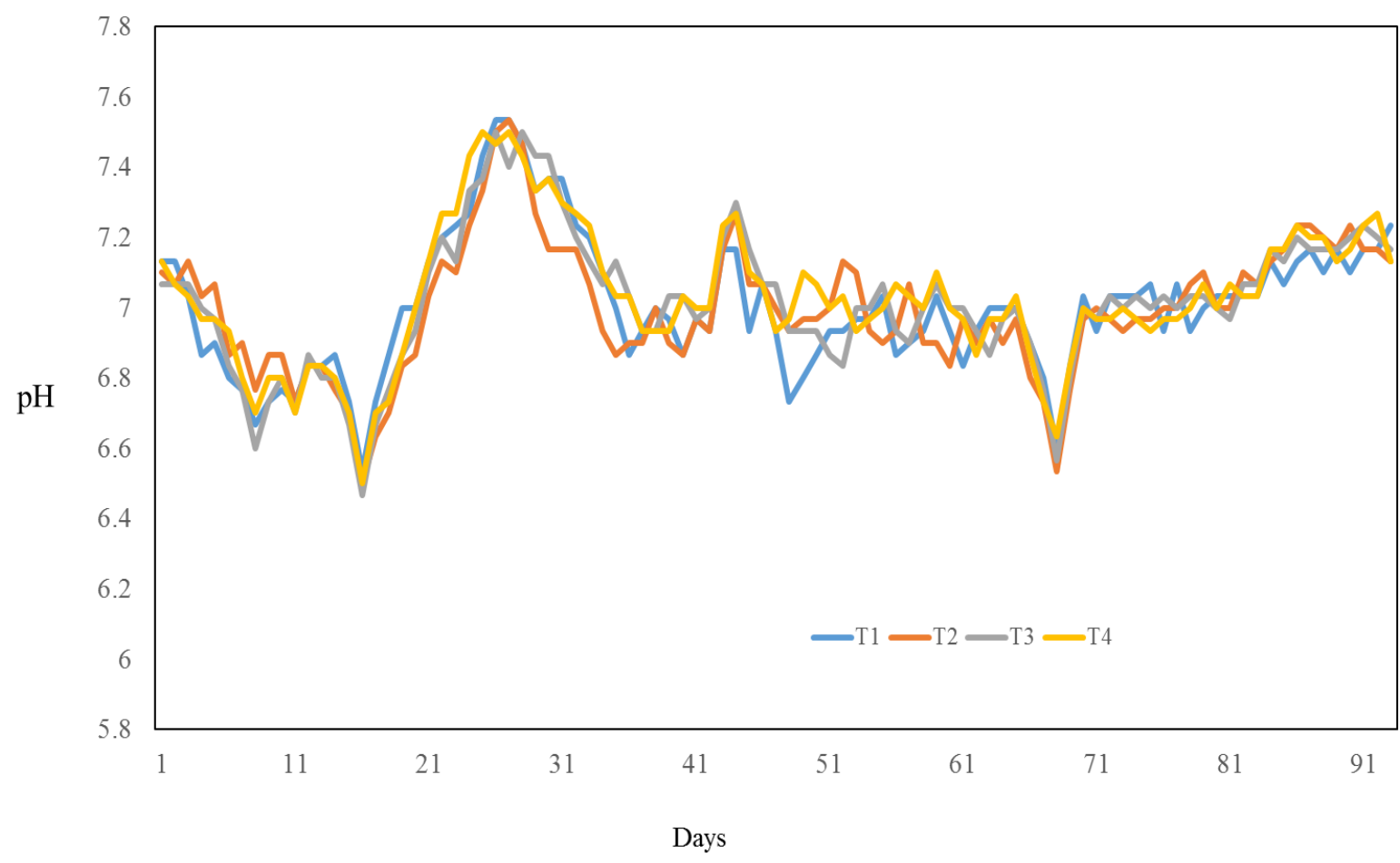

Figure 1. Changes in water $\mathrm{pH}$ recorded for the four treatments during the study 


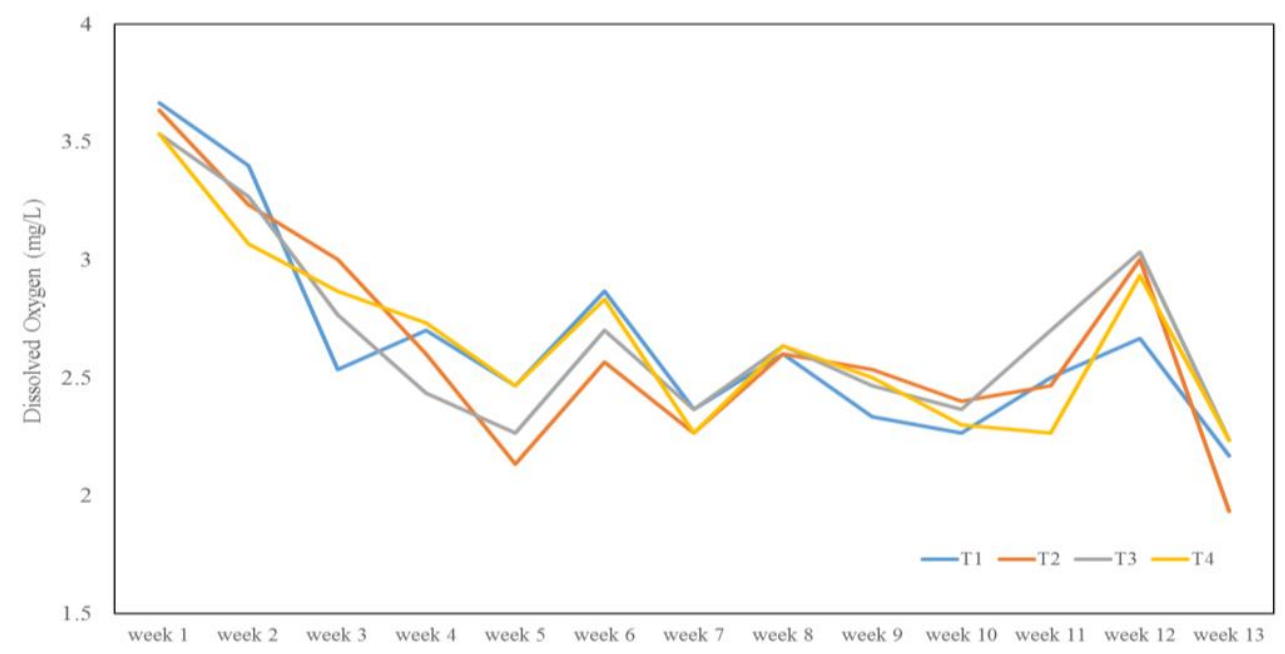

Figure 2. Dissolved oxygen content of treatments during the study

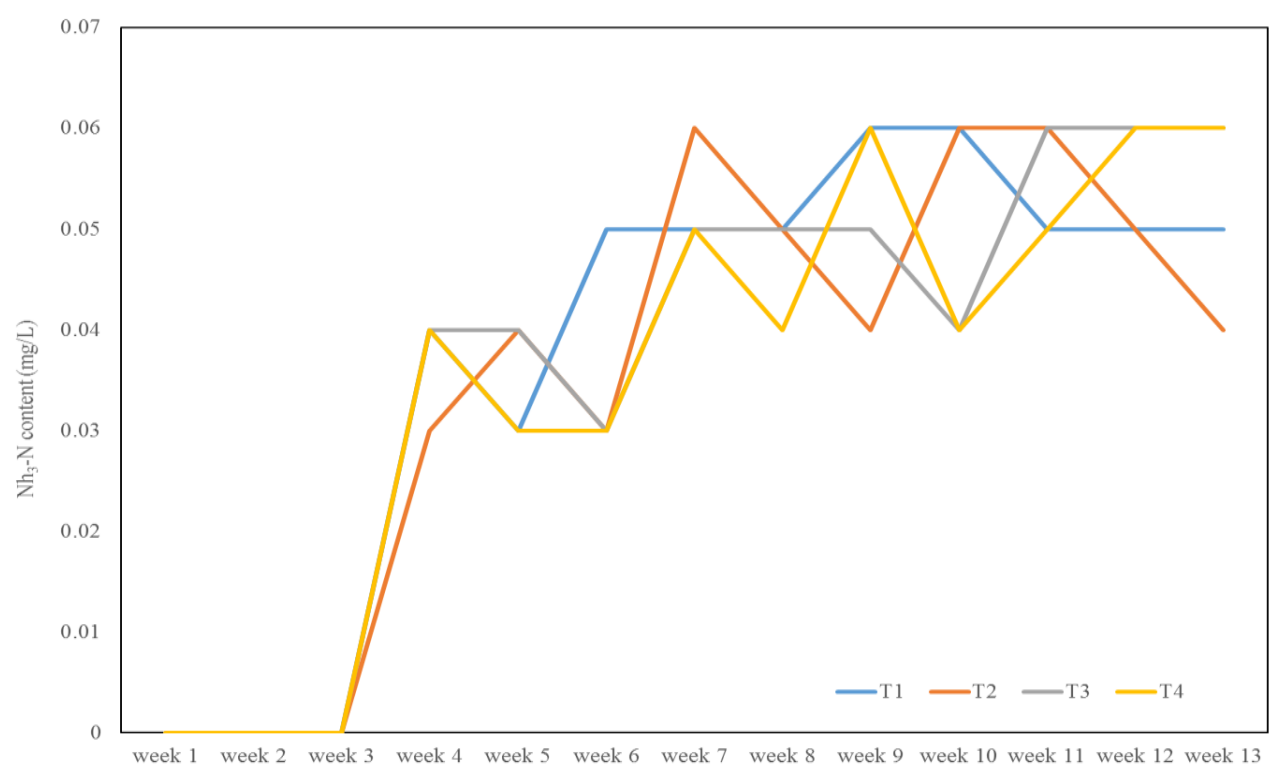

Figure 3. Changes in NH3-N content during the study

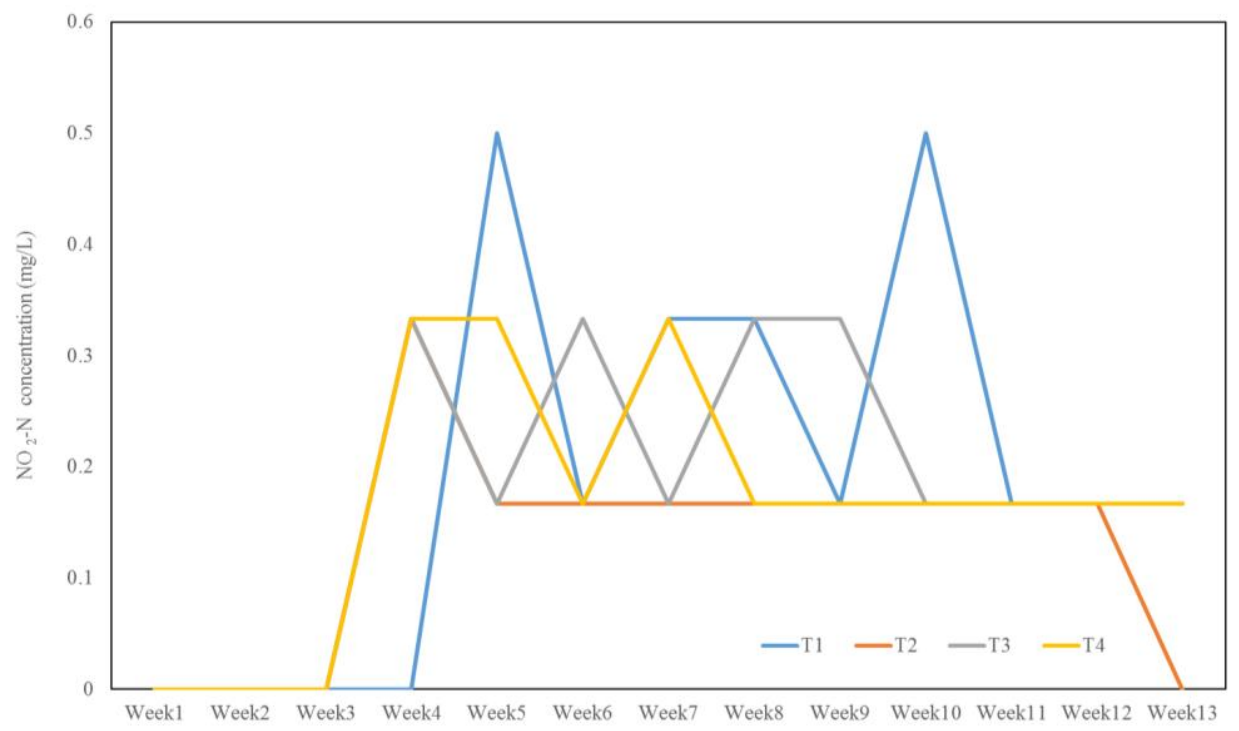

Figure 4. Changes in $\mathrm{NO}_{2}-\mathrm{N}$ content monitored during the study

\section{AQUACULTURA INDONESIANA}

An International Journal of Indonesian Aquaculture Society (www.aquasiana.org)

(C) Copyright by Indonesian Aquaculture Society 2016 


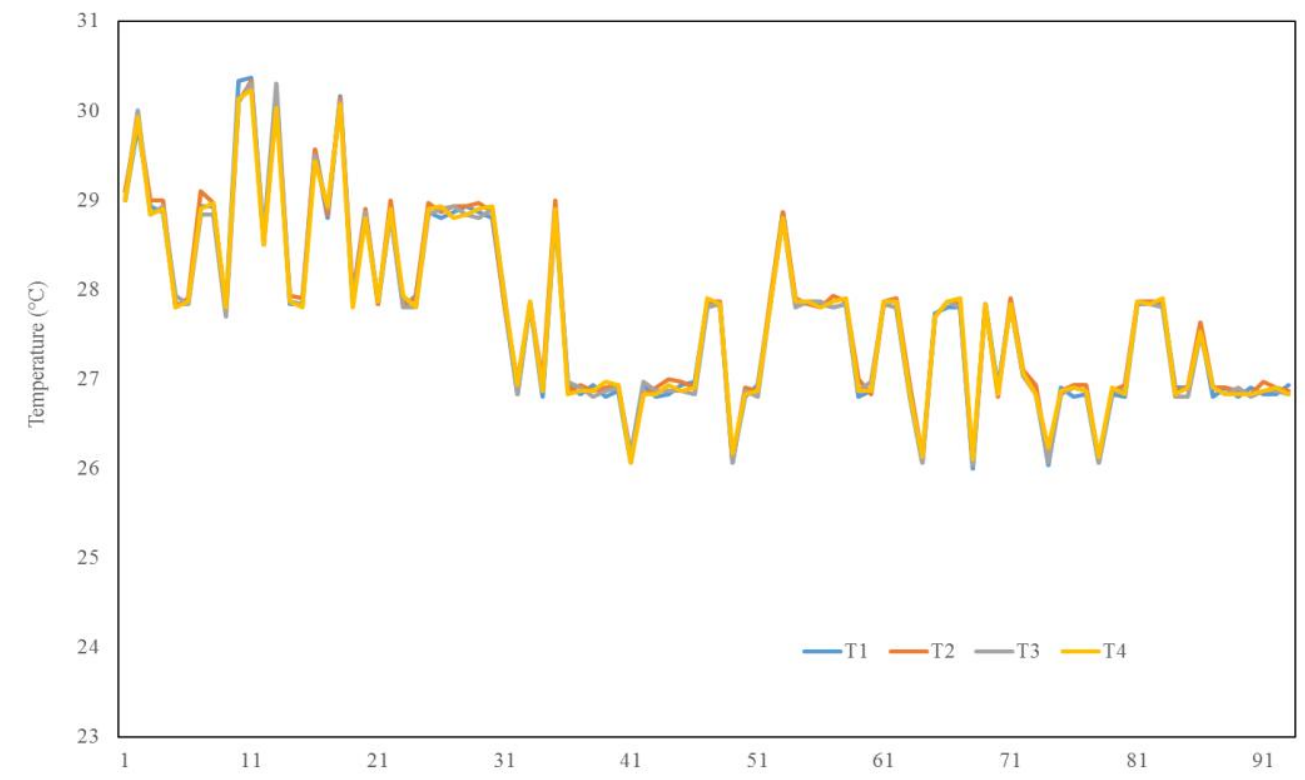

Figure 5. Variation in water temperature of the treatments monitored during the study

\section{Discussion}

\section{Effect of reducing fish oil content on growth}

\section{performance of Tra Cat fish}

Decrease of fish oil in the negative control diet resulted in lower final body weight by $19 \mathrm{~g}$ and body weight gain by $19.14 \mathrm{~g}$ compared to the positive control respectively $(P>0.05)$. Specific growth rate decreased by $0.23 \% /$ day and the survival showed a decline by $4 \%$. FCR increased by 11 points. Protein efficiency ratio reduced by 0.08 with a corresponding decrease in protein retention $(\%)$ by $1.65 \%(P>0.05)$. Lipid retention $(\%)$ was comparable to that of the positive control.

Reduction in the fish oil content of diet produced a significant impact on growth performance of Tra fish probably due to important role played by dietary lipid as a source of energy and essential fatty acids necessary for fish growth and development. A supplementation of lipid rather than carbohydrate as a non-protein energy source is generally more effective for increasing dietary energy level because lipid is an energy-dense nutrient that is readily metabolized by fish, especially by carnivorous fish (NRC, 1993).

\section{Effect of LYSOFORTE ${ }^{\mathrm{TM}}$ addition on growth performance of diets with low fish oil conten}

LYSOFORTETM addition to negative control diets at $0.5 \%$ dosage helped to improve body weight by $16.14 \mathrm{~g}$ and body weight gain by 16.08 g respectively $(P>0.05)$. Specific growth rate also improved by $0.18 \%$ day $(P>0.05)$ with a corresponding improvement in survival by $6.7 \%$ compared to the negative control treatment. There was an improvement in FCR by 1 point. Protein efficiency ratio increased by 0.22 with a corresponding improvement in protein and lipid retention of $4.89 \%$ and $27.26 \%$ respectively $(P>0.05)$.

At a higher dosage of $0.1 \%$, LYSOFORTETM supplementation improved the final body weight by $25.78 \mathrm{~g}$ and body weight gain by $25.74 \mathrm{~g}$ respectively $(P>0.05)$. Improvement in specific growth rate with $0.1 \%$ LYSOFORTE $^{\text {TM }}$ was found to be $0.28 \% /$ day $(P>0.05)$, with a $6.7 \%$ improvement in survival. FCR improvement was found to be higher (11 points). Protein efficiency ratio improved by 0.11 with a corresponding improvement in protein retention by $3.63 \%(P>0.05)$. Interestingly, lipid retention was found to improve by $37 \%$ compared to negative control $(P>0.05)$.

\section{Environmental changes during the study}

Water quality measurements indicated that water temperature fluctuated from $26.0^{\circ} \mathrm{C}-$ $30.5^{\circ} \mathrm{C}$ during the experiment (Figure 5) This fluctuation is due to the change in temperature of the surrounding environment. However, this range of temperature is suitable for growth of Tra catfish. As shown in the Figure 1, there is no significant difference in $\mathrm{pH}$ values of all the treatments, and the $\mathrm{pH}$ range of water stays in the 
suitable condition for growth of Tra catfish. DO concentration of water was found to be between 2.0 to $3.8 \mathrm{mg} / \mathrm{L}$ during the experiment due to change of water 3 to 4 times per week (Figure 2). These DO values are in the best condition for well-being and growth of Tra catfish. The $\mathrm{NH}_{3}-\mathrm{N}$ content of water at the treatments slowly increased from 0 to $0.06 \mathrm{mg} / \mathrm{L}$ during the experiment, which is still within the acceptable range for the growth of Tra catfish (Figure 3). $\mathrm{NO}_{2}-\mathrm{N}$ content of water fluctuated from $0-0.5$ $\mathrm{mg} / \mathrm{L}$ and was within the acceptable range suitable for fish culture (Figure 4).

In general, the results of environmental measurements show that the environmental factors including daily temperature, daily $\mathrm{pH}$, weekly DO, weekly $\mathrm{NH}_{3}-\mathrm{N}$ and weekly $\mathrm{NO}_{2}-\mathrm{N}$ were in the suitable range for health and growth of fish and in compliance with the standard of water for catfish culture

The positive effects of LYSOFORTETM supplementation on growth performance and nutrient retention of Tra Catfish observed in this study may be due to the beneficial effects of phospholipids in improving fish larval development, including growth and survival, digestive functions and skeletal development. Dietary phospholipids have been reported to cause integrative effects on fish growth and survival. They are known to exert a signfiicant effect on lipid absorption and transport (Fontagné et al., 2000; Izquierdo et al., 2000; Morais et al., 2006) and accumulation of lipid droplets in the enterocytes of fish larvae (Diaz et al., 1997; Fontagné et al., 1998; MacQueen-Leifson et al., 2003; Gisbert et al., 2005). In a recent study, the level and class composition of dietary phospholipids was found to impact several biochemical and morphological parameters including growth during the immature fry phase of atlantic salmon (De Santis et al., 2015). The same study showed that, at the gene expression level, phospholipid biosynthetic pathways were not affected by dietary phospholipid level or composition in salmon fry at $1990^{\circ} \mathrm{dpf}$, which could reflect that phospholipid biosynthesis pathways were not fully developed at this early life stage.

In conclusion, the observed improvements in growth performance and nutrient retention further supports the potential of LYSOFORTETM, a bio-emulsifier with a combination of lysophopsholipids and phospholipids in improving the digestion and absorption of nutrients.

\section{Summary and conclusion}

This study was designed to evaluate the beneficial effect of LYSOFORTETM, when used to replace the dietary fish oil in Tra Catfish diets. Results demonstrated that growth performance and nutrient retention of LYSOFORTETM supplemented negative control diets were found to be better than negative control diets. LYSOFORTETM supplementation@0.1\% level performed on par with positive control diets. This result indicated that LYSOFORTETM can help Catfish producers to formulate diets with less fish oil level and improve the profitability. From the results of this experiment, it can be concluded that LYSOFORTETM can either be used to partially replace the expensive fish oil to improve profitability or be added "on top" in low fish oil diets to enhance growth performance. Future studies using Lysophospholpids should aim to further elucidate the biochemical and molecular changes triggered by different types of Lysophospholipids and their combination in fish and the mechanisms associated with lipid transport and phospholipid biosynthesis during different stages of fish growth.

\section{References}

Coutteau, P, I. Geurden, M.R. Camara, P. Bergot, and P. Sorgeloos.1997. Review on the dietary effects of phospholipids in fish and crustacean larviculture. Aquaculture, 155: 149-164.

Cahu, C., J. Zambonino-Infante, and V. Barbosa. 2003.Effect of dietary phospholipid level and phospholipid: neutral lipid value on the development of sea bass (Dicentrarchus labrax) larvae fed a compound diet. $B r . J$. Nutr., 90: 21-28.

Diaz J.P., E. Guyot, S. Vigier, and R. Connes. 1997. First events in lipid absorption during postembryonic development of the anterior intestine in gilthead sea bream. Journal of Fish Biology, 51:180-192.

Daprà F, I. Geurden, G. Corraze, D. Bazin, J. Zambonino-Infante, and S. FontagnéDicharry. 2011. Physiological and molecular responses to dietary phospholipids vary between fry and early juvenile stages of rainbow trout (Oncorhynchus mykiss). Aquaculture, 319: 377-384.

De Santis, C., J.F. Taylor, L. Martinez-Rubio, S. Boltana, and D.R. Tocher. 2015. Influence of development and dietary phospholipid content and composition on intestinal transcriptome of Atlantic salmon (Salmo salar). PloS one, 10 (10), p.e0140964. 
Fontagné, S., I. Geurden, A.M. Escaffre, and P. Bergot. 1998. Histological changes induced by dietary phospholipids in intestine and liver of common carp (Cyprinus carpio L.) larvae. Aquaculture, 161:213-223.

Fontagné, S., L. Burtaire, G. Corraze, and P. Bergot. 2000. Effects of dietary mediumchain triacylglycerols (tricaprylin and tricaproin) and phospholipid supply on survival, growth and lipid metabolism in common carp (Cyprinus carpio L.) larvae. Aquaculture, 190: 289-303.

Gisbert E., L. Villeneuve, J.L. Zambonino Infante, P. Quazuguel, and C.L. Cahu. 2005. Dietary phospholipids are more efficient than neutral lipids for long-chain polyunsaturated fatty acid supply in European sea bass Dicentrarchus labrax larval development. Lipids, 40:1-11.

Izquierdo, M.S., J. Socorro, L. Arantzamendi, and L. Hernadez-Cruz. 2000. Recent advances in lipid nutrition in fish larvae. Fish Physiology and Biochemistry,22: 97-107.

Morais, S., M.J. Caballero, L.E.C., Conceição, M.S. Izquierdo, and M.T. Dinis. 2006.
Dietary neutral lipid level and source in Senegalese sole (Solea senegalesis) larvae: effect on growth, lipid metabolism and digestive capacity. Comparative Biochemistry and Physiology Part B, 1444: 57-69.

National Research Council (NRC). Nutrient Requirements of Fish and Shrimp. Washington, DC.: National Academy Press; 2011.

MacQueen Leifson R., J.M. Homme, O. Lie, R. Myklebust, and T. Strøm. 2003. Three different lipid sources in formulated startfeeds for turbot (Scophthalums maximus L.) larvae - effects on growth and mitochondrial alterations in enterocytes. Aquaculture Nutrition, 9: 33-42.

Taylor, J.F., L. Martinez-Rubio, J. del Pozo, J.M. Walton, A.E. Tinch, H. Migaud. 2015. Influence of dietary phospholipid on early development and performance of Atlantic salmon (Salmo salar). Aquaculture, 448: 262-272. 